\title{
FUNDAMENTAL PRINCIPLE OF INTERNATIONAL HUMAN RIGHT LAW-BASIS FOR THE RIGHT TO LIFE OF THE UNBORN CHILD
}

\author{
Ganiat Mobolaji Olatokun* and Rusniah Ahmad ${ }^{1}$
}

\begin{abstract}
The contention that an unborn child has the right to life has been visited with several oppositions from all works of life, all over the world. Most people do not accept the view that an unborn child possesses any form of human right which is to be protected because, that child is yet to be born into the world. It is however an established fact that, the fundamental principle of international human right instrument is to uphold the dignity and sanctity of all human persons, whether born or unborn. This shows that international human right instruments are founded on the basis of natural law. This study set out to investigate the core principle of international human right law. By so doing, the actual values and tenents of international human right law will be revealed. This is a doctrinal research, wherein the authors set out on a fact finding mission using selected articles, books and periodicals to bring out the objective of the study. At the end of the exercise, it was revealed that no international human right law will perpetrate a principle in opposition to natural law. This being the case, the unborn child, like any other living being is vested with the inalienable right to life.
\end{abstract}

Keywords: Natural law, international human right law, right to life, unborn child.

\section{Introduction}

A fundamental issue is whether right to life extends to the unborn child. The use of different terminologies has raised the question whether 'every human being' has a more expansive meaning than

\footnotetext{
Doctoral law student, School of Law, College of Law, Government and International Studies. Universiti Utara Malaysia. kazgan2000@yahoo.com.

Dean, School of Law, College of Law, Government and International Studies. Universiti Utara Malaysia.
} 
usually attributed to 'every person' in particular, whether it also includes the unborn child. ${ }^{2}$

At the national level, this is determined generally by policy rather than by law, and an overwhelming practical consideration in many jurisdictions has been the need to preserve laws that provide for abortion. ${ }^{3}$

At the international level however, the rule regarding the protection of life before birth could be considered as 'jus cogens' (final norm of general international law). Under International law, the unborn child is protected, and it is not permissible to allow a liberal abortion agenda. ${ }^{4}$

The contentions that an unborn child is not literally a person, who deserve any form of protection, are mere assertions of opinion. An opinion which is not universally shared in the same way that the various human rights instruments are universally agreed upon. In fact, it is an opinion which is in conflict with the universally agreed human rights instruments. ${ }^{5}$ The following paragraphs will show case

2 Heikki Ikheimo and Arto Laitinen, "Dimensions of Personhood" Journal of Consciousness Studies, 14 No.56 (2007): 6-12. Also, "Rights of the Unborn Child" http://www.life.org.nz/ abortion/aort ionlegalkeyissues/rightsunbornchild/ (accessed March 21, 2013).

$360 \%$ of the world's 1.55 billion women of reproductive age (15-44) live in countries where abortion is broadly legal. The remaining $40 \%$ live in countries where abortion is highly restricted. Susan Cohen, "Facts and Consequences: Legality, Incidence and Safety of Abortion Worldwide" Guttmacher Policy Review 12, no.4 (2009). http://www.guttmacher. org/pubs/gpr/12/4/gpr120402.html (accessed June 15, 2012). Siegrid Tautz, “(un) safe Abortion, A Review and Discussion Paper" Federal Ministry for Economic Cooperation and Development. Health and Population, Supraregional Project: Promotion of Reproductive Health. 4320 (2004): 7. http://www.giz.de/Themen/de/dokumente/de-disk-ssa4(1).pdf (accessed November 20, 2011). Anika Rahman, Laura Katzive and Stanley k. Henshaw, "A Global Review of Laws on Induced Abortion, 1985-1997” International Family Planning Perspectives 24, no.2 (1998):57. http://www.guttmach er.org/pubs/journals/2405698.html/ (accessed November 20, 2011).

4 Ligia M. De Jesus, "Re-Visiting Baby Boy V. United States: Why the IACHR Resolution did not effectively Undermine the Inter-American System on Human Rights' Protection of the Right to Life from Conception" (2011) Florida Journal of International Law, 23, 136226.

5 The international law upholds the unborn child's right to life. Patrick J. Flood, "Does International Law Protect the Unborn Child?" in Life and Learning XVI: Proceedings of the Sixteenth University Faculty of Life Conference at Villanova University, 2006 ed. Joseph W. Koterski (Washington DC: University Faculty of Life, 2007), 3. 
that the fundamentally agreed principle of international human rights instruments is geared towards protecting the child from conception.

\section{Natural Law and the Universal Declaration}

Most people who study jurisprudence or political philosophy are invited at some stage to read Thomas Aquinas's "treaties on law". 6 Here, they read his definition of Natural Law as participatio legis aeternae in rationali creatura: the participation of the eternal law in rational creatures. Each of us is not only subject to God's providence, but is actually a participant. Thus, Natural Law is concerned with the reason whereby, we discern what is good and what is bad. This is simply the impress in us of the divine light. However, some people are more receptive of this light than others, it is worthy to note that, every (sane and conscious) person grasps the general principle of practical reasonableness. ${ }^{7}$

The Natural Law originates nothing, sustains nothing, they are merely responsible for uniformity in sustaining what has been originated and what has been sustained. ${ }^{8}$ Hence, when it comes to establishing a strong conceptual frame work of human right principles, the theories of relativism and positive law, untethered from universal principles, has no place in the drafting of the Universal Declaration. ${ }^{9}$

'Natural law ${ }^{10}$ is definitely the only valid bulwark against the arbitrary power or the deception of

Thomas Acquinas, Question 90-7 of the first part of the second part of his Summa Theologiae.

7 John Finnis, Natural Law and Natural Right (Oxford, NY: Oxford University Press, 2011), 398-402; William E. May, Introduction to Moral Theology (Huntington: Our Sunday Visitor Publication, 2003), 83.

8 Henry Drummond, Natural Law in the Spiritual World (Rockville MD: Arc, Manor Publishers, 2008), 20 .

9 Rita Joseph, Human Right and the Unborn Child (Leiden, Boston: Martinus Nijhoff Publishers, 2009), 39. Classical Roman Jurists, Sir William Blackstone and a host of other writers, fancy that a rule of law made by judicial decision on a pre-existing custom exists as positive law. John Austin and Robert Campbell, Lectures on Jurisprudence, or the Philosophy of Positive Law (Clark NJ: The Law Book Exchange, 2004), 36; Hans Kelsen, General Theory of Law and State (Clark NJ: Lawbook Exchange, 2007), 396-397.

10 Acquinas, "Treaties". 


\section{ideological manipulation. ${ }^{11}$ The knowledge of this law inscribed on the heart of man increases the progress of the moral conscience. ${ }^{12}$}

The writing of the Universal Declaration ${ }^{13}$ represents such a bulwark. It also represents a tremendous leap in the progress of the moral conscience. ${ }^{14}$ The drafters of the Declaration clearly understood their role as representatives of the conscience of mankind. Hence, the dignity and worth of human person is the founding premise of the Universal Declaration. ${ }^{15}$ Eleanor Roosevelt, ${ }^{16}$ Dr. Johannes

11 Human right expert, like professor Tore Lindholm was right in his understanding that what he calls, 'a genuine natural rights doctrine' of human rights excludes interpretations of historically changing societal conditions from being an essential part of the rationale of human right. Lindholm Tore, "Article 1" in The Universal Declaration of Human Right: A Common Standard of Achievement eds. Godnundur Alfredson and Asbjorn Eide (The Hague: Nijhoff, 1999), 71-3; Joseph, Unborn Child, 37.

12 This statement was made by Pope Benedict XVI, who was as a youth; saw firsthand the disastrous adaptation of law to Nazi ideology; Joseph, Unborn Child, 41. Abortion today, is not a different act from that of doctors purposely killing fetuses and new born babies in order to preserve Nazi racial social purity; Joseph, Unborn Child, 316. Natural law is thought best to combat the arbitrariness of the power of the Nazi movement which is rooted in racism. The extent of such power is evidenced in George J. Annas and Michael A. Grodin, The Nazi Doctors and the Nuremberg Code: Human Right in Human Experimentation (Oxford NY: Oxford University Press, 1995), 22; Dennis R. Alexander and Ronald L. Numbers, Biology and Ideology from Descartes to Dawkins (Chicago, London: University of Chicago Press, 2010), 202.

13 The declaration is universally regarded as an authoritative elaboration of the human rights provisions of the United Nation Charter. Many, if not all of the rights elaborated in the Declaration are widely recognized as constituting rules of Customary International Law. Samuel M. Natale and Mark B. Fenton, Business Education and Training: On the Threshold of the Millennium (Lanham Md: University Press of America, 2000), 208.

14 Joseph, Unborn Child, 39.

15 Ibid.39. In view of the Nazi's crime against humanity, the United Nation Commission on Human Rights was charged with writing a declaration of human rights which reaffirms the faith in fundamental human right in the dignity and worth of human person... this is the basic premise; The Charter that the peace and security of mankind are dependent on mutual respect for the rights and freedoms of all, in Suzzane Mclntire and William E. Burns, Speeches in World History (New York: Facts on File, 2009), 387-391; Preamble of the Universal Declaration of Human Right. G.A Res. 217(A) (III), UN GAOR, $3^{\text {rd }}$ Sess, Supp. No 127 at 71, UN Doc A/180 (1948); Mary Ann Glendon, A World Made New (New York: Random House, 2001), 175; Vicki C. Jackson, "Constitutional Dialogue and Human Dignity: States and Transformational Constitutional Discourse" Montana Law Review 65, (2004): 15.

16 She was the former first lady in the white house (1933-1945). She became head of the United Nation Commission on Human Rights. At a meeting of the United Nation in Paris, 1948, she addressed United Nations officials, diplomats and world leaders at the Sorbonne University on the document she helped write- the Universal Declaration of Human Rights. Mclntire and Burns, Speeches in World History, 387. 
Van Aggelen, ${ }^{17}$ Charles Malik, ${ }^{18}$ and a host of others who had close connections with the drafting of the Declaration, made constant reference to the premise, basis and foundation of the Declaration as the respect for the dignity, sanctity as well as worth of human person.

It can therefore be said that, the concepts of dignity, sanctity, status, and worth of individual person underpin the Declaration's understanding and acceptance of the first principle of natural law, that is, the moral importance to do good and avoid evil, and emanating from this, the precept that affirms preservation of any human life. Natural Law principles such as these, found concrete expression in the Declaration, and were declared by the drafters to be universal. ${ }^{19}$ This being the case, one Fereydoun Hoveyda, ${ }^{20}$ looking back to his experience as a young Iranian law graduate assistant to the Iranian delegate in the third committee debates, confirms this great emphasis on the universality of the Declaration. He is however troubled that the very concept of universality of the Universal Declaration of Human Rights is being harmed by several fragmentations being imported into the declaration which, according to him has the tendency to nullify the Declaration. In his words;

Abandoning the Declaration in the name of cultural differences would constitute a setback. There is no Islamic, Buddhist, Hindu, Zoroastrian, Christian, Judaic

17 He was a close associate of John Humphrey, Director of the United Nations Division of Human Rights, first appointed to oversee the drafting of the Universal Declaration. Joseph, Unborn Child, 40; Van Aggelen Johannes, "The Preamble of the United Nations Declaration of Human Rights" Denvor Journal of International Law and Policy 28, No.2 (2000): 133-4.

18 A Lebanese philosopher and diplomat, he was president of the United Nations Economic and Social Council. He served as rapporteur of the Commission on Human Rights at the time of drafting the Universal Declaration. Joseph, Unborn Child, 39; Charles Malik, International Bill of Human Rights (United Nations Bulletin, 1948), http://www.udhr. org/history/ibrmalik.htm (accessed January 29, 2013).

19 Joseph, Unborn Child, 40.

20 Last surviving participant in the final drafting of the Universal Declaration of Human Right. He died November 3, 2006. 
etc rights. There are human rights, pertaining to human beings where ever they live, and whatever their creed $^{21}$

It is hereby stated, adding to Hoveyda's contention, that abandoning the concept of universality in the name of radical feminist ideology would also constitute a setback. ${ }^{22}$ For, there are no feminist rightsthere are only human rights, pertaining to human beings where ever they live, pertaining even to the smallest human being, who, for a short nine months, enjoy the natural right to live and grow in utero.

There is no evidence what so ever that, the drafters ever contemplated the removal of legal protection from the unborn children. If the drafters were clear and united about anything, they were clear and united on this, 'henceforth, absolutely, no one was to be excluded from human right protection and no jurisdiction was ever again to be exempted from the universality of that protection' ${ }^{23}$ Thus, giving the human child at the early stages of development other names such as, 'embryo' or 'fetus', and referring to the child as 'it', ${ }^{24}$ does not alter the child's human nature or the child's entitlement 'by nature' to the inherent dignity ${ }^{25}$ and inalienable rights of all members of the

21 Joseph, Unborn Child, 41; Hoveyda Fereydoun, "The Universal Declaration and 50 Years of Human Rights"(1998) Transnational Law and Contemporary Problems 8, 435. Hence, the Universal Declaration drew upon the intellectual well springs of Africa, the Americas, Asia, and Europe in a distillation of universal rights; Eva Brems, Human Rights: Universality and Diversity (The Hague: Nijhoff, 2001), 7. The Universal Declaration of Human Rights drew on the experiences of non-Western societies and the valid aspirations of the people within those societies to overcome the oppression and repression. Stephen P. Marks, "From Single Confused Page to the Dialogue for Six Billion Persons: The Root of the Universal Declaration of Human Rights in the French Revolution"(1998) Human Right Quarterly 20, No.3, 485. The universality concept implies a positive attitude to cultural and ideological diversity in the sense that, it interprets the multitude of different cultures and philosophies; Brems, "Human Rights" 3-20; Makau Mutua, "Standard Setting in Human Rights: Critique and Prognosis" (2007) Human Right Quarterly 29, 556.

Joseph, Unborn Child, 41.

23 Joseph, Unborn Child, 36.

24 Capelon et al, "Human Rights Begins at Birth: International Law and the Claim for Fetal Rights" Reproductive Health Matters (2005)13, No.26,120-9.

25 Considering the fact that 'dignity' is becoming common place in the legal text providing for human right protection in many jurisdiction, it is however contended here that, what must be borne in mind is the spirit and intents of the drafters of the Universal Declaration of Human Rights that human dignity is a symbol of natural law, that is, the moral imperative to do good and avoid evil. Christopher McCrudden, "Human Dignity and Judicial Interpretation of Human Rights" European Journal of International Law (2008)19, No.4, 656. 
human family. ${ }^{26}$ The term inalienable rights of all members of the human family applied to the child before birth. The right to life is inalienable. This suggests that, this right cannot be taken from the child by anyone.

It is not the act of 'being born' that grants or confers human rights. It is 'being human' that confers human rights and the child before birth, at whatever stage of life, embryonic or foetal, is a distinct human being, a new and irreplaceable human being, an identifiable member of the human family whose rights are equal and inalienable. Hence, the contention by Capelon et al, that the wordings of 'Articles 1' of the Universal Declaration of Human Rights which says that, 'All human beings are born free and equal' excludes the unborn child from the human right to life granted by 'Article 3' of the Declaration, because the unborn child is not 'born'27

Although there were several definitions giving to the word 'born' in 'Article 1' during the negotiation history of the Declaration, it is here stated that, the understanding of the word 'born' as used within the Declaration can only be given by those who were part and parcel of the drafting of the Declaration. This understanding was given by Charles Malik, who was the chairman ECOSOC, and of the third committee that steered the Universal Declaration to its conclusion. In his words,

Then in Article 1, human beings are said to be 'born free' and equal in dignity and right. Certainly, the word 'born' means that our freedom, dignity and rights are natural to our being and are not generous grant of some external powers...

${ }^{26}$ Joseph, Unborn Child, 44-46. A child before birth is a member of the human family biologically, genetically and genealogically. To be eligible for membership of human family, one has to be human. Morsink Johannes, "Women's Right in the Universal Declaration"(1991) Human Right Quarterly 13, 230; Joseph, Unborn Child, 48. Present in former president Regan's description of the fetus, was the notion of public fetus. The fetus to him was one of America's unborn children and a member of the human family. The fetus was not of the mother; the fetus was of the society. Michael Weiler and W. Barnett Pearce, Regan and Public Discourse in America (Alabama: University of Alabama Press, 1992), 278. The fetus is thinking, sensing, feeling and learning about life in that watery world. We need to revisit the roots of our humanity as members of the human family... Roy Ridgway and Simon H. House, The Unborn Child: Beginning of a Whole Life and Overcoming Problems of Early Origin (London: Karnac, 2006), xiv.

27 Capelon et al, "Human Right Begins at Birth", 120-9. 
This quotation was from the speech on Human Rights to the U.S Chambers of Commerce Committee on International, Political and Social Problems given at the Waldorf Astoria in New York, November 4, 1949. With this understanding, the views of Capelon et. al. are false. ${ }^{28}$

Having established that the Universal Declaration of Human Rights was established on the basis a natural law, ${ }^{29}$ which recognizes the dignity, sanctity and worth of human persons, from which the right to life is thereby granted to everyone including the unborn child, it is here argued that the prohibition of abortion is a legal norm considered so fundamental to its peremptory norm of international law. The protection of the child before as well as after birth is a fundamental principle of jus cogens of our system of international protection of human right based on universal recognition of international community. ${ }^{30}$

The protection of the child before as well as after birth is recognized irrevocably by the Universal Declaration of Human Rights as a common standard of achievement for all peoples and for all nations. ${ }^{31}$ It is on this basis and premise that, all other International Human Right Laws, except the Protocol to the African Charter on Human and People's Rights on the Rights of Women in Africa, ${ }^{32}$ recognizes the protection of the child both before as well as after birth.

28 Joseph, Unborn Child, 58.

29 The right to life, because it is inalienable rules out abortion. The natural law principle relevant here is that, a human entity should be allowed to persist in being and that, one must not directly attack any basic good in any person, not even for the sake of avoiding bad consequences. That this basic aspect of human well being is never to be directly suppressed, is cited by Professor John Finnis as the principle of natural law that provides the rational basis for absolute human rights, for those human rights that prevail sempe et ad (always and on every occasion) and even against the most specific human enactment and commands. Joseph, Unborn Child, 42. Ibid.105.

31 Ibid. ; the Preamble Universal Declaration of Human Rights.

32 The arbitral exception of assault, rape and incest in Article 16 ( c) of the Women's Protocol purporting to justify the authorization of abortion are not consistent with the long standing human right obligations towards the unborn child, and thus, not valid. Joseph, Unborn Child, 250. This is the only international human right instrument representing a departure from the general pattern of other international human right laws, and according to a writer, a suggestion has been proffered on how the unusual provision of abortion within this instrument can be dealt with. Flood, "Protect the Unborn Child", 38. 


\section{Other International Human Right Laws}

The Universal Declaration of Human Rights have inspired all other human right laws and consequently, all other International Human Rights laws are consistent in their right to life provisions of all citizens of the world generally, and in particular, the right to life of the unborn. Abortion is frowned at by all international human right instruments, by their provisions as regards the right to life of the unborn.

Article 6 (1) of the International Covenant on Civil and Political Rights (1966) provides that,

Every human being has the inherent right to life. This right shall be protected by the law. No one shall be arbitrarily deprived of his life.

Article 6 (5) further provides that,

Sentence of death shall not be carried out on pregnant women

To underscore the importance of the right to life, Article 4 of the Covenant provides that not even

In time of public emergence threatening the life of the nation' may the state derogate from any part of Article 6

The foregoing provisions and particularly the ban on the execution of a pregnant woman are clear expression of a shared understanding that the unborn child is a human being, who as such has an independent claim to protection and merits official recognition and intercession. The basic principle of criminal law justice is that the guilty shall be punished and the innocent shall not, and international human right instruments reflect this logic by granting concession to an innocent foetus in its mother's womb. ${ }^{33}$

William A. Scabas, The Abolition of the Death Penalty in International Law, $2^{\text {nd }}$ ed (Cambridge UK: Cambridge University Press, 1997), p. 25. 
The Convention on the Rights of the Child (1989), which was preceded by a Declaration of the Right of the Child (1959), includes in its preamble a significant affirmation of the rights of the unborn

Whereas the child by reason of his physical and mental immaturity needs special safeguards and care, including appropriate legal protection before as well as after birth .

There is in fact a chain of logic extending from the preamble through Article 1 and 6. In the preamble, it is the 'child' that needs 'appropriate legal protection before as well as after birth'. In Article 1, 'the child' is every human being below the age of eighteen years, which clearly does not exclude the unborn (by virtue of the preamble), as it does exclude human beings who have attained the age of eighteen. And in Article 6, it is 'every child' who in para. 1, 'has the inherent right to life and in para. 2, it is 'the child' whose 'survival' state parties shall ensure to the maximum extent possible. In all these references, it is the unborn as well as the born children ${ }^{34}$ that is being referred to.

Thus, while Articles 1 and 6 do explicitly endorse a right to life for the unborn child and state's obligation to protect the right, the weight of these articles taken together with the preamble provides solid ground for the claim that the unborn child is entitled to legal protection under the Convention. There is no evidence in the Convention of a right to abort. Indeed, there is instead, a distinct preference for life of the unborn as well as the born. ${ }^{35}$

The Geneva Conventions are evidence of the international community's intention to include the unborn as beneficiaries of international protection. Hence, the Fourth Geneva Convention (Protection of Civilian Persons in Times of War) (1949), provides under Article 16 that, expectant mothers are among those who,

shall be object of particular protection and respect.

Flood, "Protect the Unborn Child", 10.

5 Ibid, 11. 
Article 14 states that expectant mothers are among those who,

shall be included in hospital and safety zones.

Article 23 provides that, expectant mothers are among those who,

shall be beneficiaries of free passage to civilians in occupied territories, of essential food stuffs, clothing and tonics intended for children under fifteen, expectant mothers and maternity cases

Article 70 of Protocol I to the Geneva Convention (1977) mentions expectant mothers among those persons to be given priority in the distribution of relief consignments as they are among the groups to be 'accorded privilege treatment or special protection'. Article 76 of Protocol I to the Geneva Convention also provides that parties to an armed conflict

shall endeavour to avoid the pronouncement of the death penalty on pregnant mothers and mothers having dependant infants...The death penalty shall not be executed...on such women.

Article 6 of Protocol II of the Geneva Convention (1977) has the same provision as Article 76 of Protocol I. The combined effect of the Fourth Geneva Convention as well as the two Protocols provides strong evidence of a widespread international commitment to the protection of the unborn human beings. ${ }^{36}$

Article 1 of the Draft International Covenant on Human Rights (1947), states that,

It shall be unlawful to deprive a person, from the moment of conception, of his life and bodily integrity

If all these international human rights instruments are consistent in their respect for the sanctity of human life, whether born or unborn, then right to choose, an aspect of reproductive rights under the Convention on the Elimination of all forms of Discrimination against Women (CEDAW) cannot be interpreted differently. Right

36 Ibid, 15. 
to choose within CEDAW ought to respect the sanctity of life of the unborn. ${ }^{37}$ The ultimate challenge of the $21^{\text {st }}$ Century is that of giving greater substance to existing norms of human rights. The lack of specific content of the 'right to choose' and 'family planning' within CEDAW has given rise to some concerns like those envisaged in this study. ${ }^{38}$

Article 12(1) of the Convention on the Elimination of All forms of Discrimination against Women provides;

States parties shall take all appropriate measures to eliminate discrimination against women in the field of health care in order to ensure, on the basis of equality of men and women, access to health services, including those related to family planning.

Reading the Convention further, Article 16(1) (e) provides;

State parties shall take all appropriate measures
to eliminate discrimination against women in all
matters relating to marriage and family relations and
in particular shall ensure, on the basis of equality of
men and women; the same rights to decide freely
and responsibly on the number and spacing of their
children and to have access to the information,
education and means to enable them exercise these
rights

37 A detailed understanding of the preamble (text) to CEDAW reveals that, due regard and recognition is given to the dignity of human person.

38 The lack of specific content of the term 'family planning' in international documents, like CEDAW seems to have given rise to some scepticism. There exist considerable difficulties in reaching consensus worldwide on the exact meaning of the notion. Maja Kirilova Erickson, Reproductive Freedom: In the Context of International Human Rights and Humanitarian Law Kluwer Law International (2000). CEDAW not only defines equality, it discusses a wide range of topics such as sexual right, reproductive right and right to health care. The Convention is very careful in addressing these issues and refers only to a woman's right to decide freely and responsibly on the number and spacing of their children and to have access to information, education and means to enable these rights. Cheshmak Farhoumand-Sims, "CEDAW and Afghanistan" (2009) 11(\#1) Journal of International Women's Studies, $136 \mathrm{http} / /$ www.bridgew.edu/soas/ jiws/Nov09/ Cheshmak.pdf Accessed 16th April 2012. 
These being the original contents of the Convention, the CEDAW general recommendation No. 24 embodying the key elements of Article 12 provide among others; ${ }^{39}$

The obligation to respect rights requires state parties to refrain from obstructing action taken by women in pursuit of their health goals. State parties should report on how public and private health care providers meet their duties to respect women's rights to have access to health care. For example, state parties should not restrict women's access to health services or to the clinics that provide those services on the grounds that women do not have the authorization of husbands, partners, parents or health authorities, because they are unmarried or because they are women. Other barriers to women's access to appropriate health care include laws that criminalize medical procedures only needed by women and that punish women who undergo those procedures. $^{40}$

Recommendation No. 24 of the CEDAW committee, contrary to the provisions of the Articles 12 and 16 of CEDAW, can therefore,

39 General recommendations of CEDAW Committees are interpretations of an accord to assist state parties in implementing their obligations. Hanna Beate Schopp-Schilling, "The Role of the Convention on the Elimination of all forms of Discrimination Against Women and its Monitoring Procedures for Achieving Gender Equality in Political Representation" (2004) 3. A paper presented at the International Institute for Democracy and Electoral Assistance (IDEA)/CEE Network for Gender Issues Conference. The Implementation of Quotas: European Experiences, Budapest, Hungary, 22-23 October, 2004. <http:// www.quotaproject.org/CS/CS_Cedawbudapest04BSS.pdf> Accessed $3^{\text {rd }}$ April 2012. The Committee on the elimination of discrimination against women was established to monitor state parties' compliance with the obligations under the convention. It also gives general recommendations on issues affecting women that deserve more attention by state parties. CEDAW and the Reporting Process to the Committee on the Elimination of Discrimination against Women: A Guide for UNICEF field Staff (2009) $7<\mathrm{http}: / /$ www. crin.org/docs/CEDAW.pdf> Accessed 16 th $^{\text {th }}$ April 2012.

40 key element no 14 under recommendation no. 24 of the CEDAW committee. <www. un.org/womenwatch/daw/cedaw/recommendations/recomm.htm $>$ Accessed $3^{\text {rd }}$ April 2012. Also, "Report of the Committee on the Elimination of all forms of Discrimination against Women" Twentieth Session (19 ${ }^{\text {th }}$ January- $5^{\text {th }}$ February 1999), Twenty-First Session ( $7^{\text {th }}-25^{\text {th }}$ June 1999), General Assembly Official Records, fifty-fourth Session Supplement No. 38 (A/54/38/Rev.1). <www.un.org/womenwatch/daw/cedaw/reports/21report.pdf > Accessed $3^{\text {rd }}$ April 2012. 
be interpreted to include abortion, ${ }^{41}$ because by its wordings, state parties should not criminalize any medical procedure needed by only women. The only medical procedure needed by women as far as reproductive right is concerned is abortion. ${ }^{42}$

Recommendation No. 24 of CEDAW committee is not a provision within the CEDAW rules. The committee has merely acted ultra vires, by giving a misleading interpretation to the 'right to choose' provision within CEDAW. The 'right to choose', contained in a human right instrument like CEDAW, stand for the protection of life of the unborn. The provision that women should be able to decide freely and responsibly on the number and spacing of their children is merely suggesting that women should plan their families adequately, by spacing their children, not that, women should abort their babies. ${ }^{43}$ Articles 12 and 16 of CEDAW can therefore be said to recognize the right to choose for women and the right to life for the unborn child.

\section{Subsequent State Practices}

In order to show that international human right laws accorded great regard and respect to the right to life of the unborn child, certain

${ }_{41}$ Within the UN, the issue of women's access to legal abortion and counselling as well as to services has been of major concern of expert members of CEDAW. Erickson, Reproductive Freedom, 301.

42 Abortion continued to be the most commonly privately funded medical procedure. Emily Jackson, Regulating Reproduction: Law, Technology and Autonomy, Oxford: Hart Publishing (2001). Abortion is a legal medical procedure and women, regardless of whether their hospitals or HMO provides abortion services have a right to information about their medical options. Congressional Record V. 148, pt 13, September 20, 2002 to October 12002 (2006) 17954. Abortion has also been referred to as 'life threatening medical procedure' in Nancy Ehrenreich, The Reproductive Rights Reader: Law, Medicine and the Construction of Motherhood New York University Press Books (2008). The American Medical Women's Association has also referred to abortion as a medical procedure. Congressional Record V. 145 pt 18, October 141999 to October 251999 at 26023.

43 This was the outcome of a recent study conducted by one of the authors in respect of her PhD thesis between March and May 2012. Most of the participants viewed the right to choose within CEDAW as synonymous to right to choose for women in order to plan the spacing and timing of their children. To them, the notion of right to choose should therefore be viewed from the angle of family planning, and not abortion. To the participants in the study, if the right to choose is viewed from the angle of child spacing and family planning, it will further enhance the health of women in order for them to be able to exercise their right to reproduce which will lead to the right to life for the unborn. 
provisions within international human right law, e. g, 'right to choose' and 'family planning' within CEDAW was left intentionally ambiguous to allow state parties to ratify the Convention. According to account of CEDAW's negotiating history, some countries were opposed to the mention of 'family planning services'. Since this (family planning services) did not exist everywhere, it could result in the refusal to ratify the convention, so the supporters of CEDAW emphasize that, the Convention calls on State Parties to take 'all appropriate measures', thereby, leaving it to State governments to determine what constitutes access to 'family planning' ${ }^{44}$ In support of this, they point out to the negotiating history of the Convention that indicates that the text ('all appropriate measures') was left intentionally ambiguous to allow State Parties to ratify CEDAW. ${ }^{45}$ To address the concerns of some Convention opponents, in 1994, the Clinton administration proposed an understanding to CEDAW that said the United States ${ }^{46}$ understand that, Article 12 permits state parties to determine which health care services are appropriate in connection with 'family planning', pregnancy, confinement and post-natal periods as well as when the provision of free services is necessary and does not mandate the provision of particular services on cost free basis. In June 2002, under the chairmanship of former senator Joseph Biden, the SFRC (Senate Committee on Foreign Relations) held hearings on CEDAW ratification in the USA. On July 30,2002 , the committee reported the Convention favourably by a vote of 12 to 7 , subject to several RUDs. One of the understandings

44 Lars Adam Rehof, Guides to the Tranvaux Preperatories of the United Nation Convention on the Elimination of All forms of Discrimination against Women (Dordrecht: Nijhoff, 1993), 143.

45 Ibid. Furthermore, still on the issue of allowance given to state parties to device their own method and approach of 'family planning', Maria Isabel Plata, as far back as 1991, urged CEDAW to issue a general recommendation clarifying the terms, women's health and 'family planning' programs. Such a recommendation would explain that, in order to comply with the convention, states need to develop comprehensive reproductive health services that empower women and not use women as a means to limit population growth, save the environment and speed development. Rebecca J. Cook, Human Rights of Women: National and International Perspective (Philadelphia: University of Pennsylvania Press, 1994), 19.

46 The reference to United States is to further buttress the assertion being made that, even the World's leader is yet to ratify CEDAW. See, "A Fact Sheet on CEDAW: Treaty for the Rights of Women" https://www.amnestyusa.org/sites/default/files/pdfs/cedaw_fact sheet.pdf (accessed August 12, 2014). This is saying that the United States has accorded right to life to the unborn child. 
was a proposal from ranking member senator Jesse Helms that stated; 'nothing in this convention shall be construed to reflect or create any right to abortion and in no case should abortion be promoted as a method of 'family planning'. This Helm's understanding was included as a compromise to alleviate the concerns of pro-life advocators who were concerned that CEDAW ratification could affect US abortion laws ${ }^{47}$

The reference to the negotiating history shows that, right from the onset, there were inhibitions expressed by state parties in respect of 'family planning' mentioned within the 'right to choose' to be taken to mean abortion. It showed that, these inhibitions was respected and acknowledged by the leverage given to state parties to adopt the meaning that best suit their countries as far as 'family planning' is concerned, showing in the main, the respect for national sovereignty and the respect for the sanctity of human persons as expressed in the preamble to CEDAW. This accounted for reservations made by some state parties.

The non-domestication of CEDAW till date as well as the continued criminalization of abortion ${ }^{48}$ by Nigeria ${ }^{49}$ has shown the necessary subsequent practice required to interpret the 'right to choose' within CEDAW and to uphold the 'right to life' of the unborn child.

International law $^{50}$ has recognized the global problem which appears particularly significant in regions where 'clashes of culture'

7 Luisa Blanchfield, United Nation's Convention on the Elimination of All forms of Discrimination against Women (CEDAW): Issues in the US Ratification Debate (Congressional Research Service, 2010), 16-18

48 Secs 232,235 Penal Code (applicable in the Northern Nigeria) and secs 228, 229 and 230 Criminal Code (applicable in the Southern Nigeria).

49 Example of a country that had ratified CEDAW, but failed to domesticate and implement it. This signifies that right to life is accorded to the unborn child by Nigeria.

50 L. Oppenheim, International Law $8^{\text {th }}$ Edition (London: Longman, 1955), 26; David Kennedy, "The Sources of International Law" American University Journal of International Law Review 2, No.1 (1987): 4, http://www.auilr.org/pdf/2/2-1-1.pdf (accessed April 9, 2012). 
are imminent. ${ }^{51}$ In such countries with marked cultural diversity ${ }^{52}$ and distinct political decentralization, culture-related divergences in interpreting human right texts are visible..$^{53}$ Hence, in a bid to interpret the 'right to choose' within CEDAW in Nigeria, the relative (limited or moderate) universalism approach ${ }^{54}$ is opted for. This approach upholds the treaty-based human right as such (or at least the core of it), but allows consideration of particular cultural aspects when interpreting the often vague formulated-human right, when filling up a margin of appreciation, ${ }^{55}$ or particularly significant, when weighting human rights and public interests. This approach shows that, any interpretation of normative texts in any country is interdependent with local and regional culture. ${ }^{56}$ Nigeria, as a country, in recognizing these facts, have interpreted 'right to choose' within CEDAW to exclude abortion.

${ }_{51}$ Karen B. Brown and David Snyder, General Report of the XVIIIth Congress of the International Academy of Comparative Law/ Rapports Generaux Du XIII Condress De L'Academie Internationale De Droit Compare (Dordrecht, London: Springer, 2012), 583. Article 31(3)( C) VCLT also acknowledges that the complex and entangled relationship between custom and treaties must be taken into account when interpreting the latter if relevant and applicable. Leena Grover, "A Call to Arms: Fundamental Dilemmas Confronting Interpretation of Crimes" European Journal of International Law 21, No.3 (2010): 543, http://www.lexisnexis.com.eserv.uum.edu.my/ap/academic/ (accessed April 19, 2012).

52 Nigeria has a population of 140 million (National Population Commission Nigeria), making it the most populous country in Africa. Anjuwon et al, "Assessment of Scholarly Publications of the Nigerian Health Science Researchers in MEDLINE/PubMed (19962007)" (2011) Sierra Leone Journal of Biomedical Research 3, No.2, 90.

53 The process of interpretation is also an integral part of the legal system in which the text is situated. Legal texts only make sense within the legal context of the system that gives them authority and meaning. Campbell McLachlan, "The Principle of Systematic Integration and Article 31(3)(c) of the Vienna Convention" (2005) International and Comparative Law Quarterly 54, No.2, 279-320, 286.

54 Other approaches are, (i) absolute relativism, which totally denies, for whatever conflicting cultural reasons, the universal or at least, quasi-universal normative effect which result from the human right treaties, and (ii) universality through culture, which confirms an inner link, not a contrast between both dimensions saying that cultural adaptation increases or even creates sociological acceptance of the normative prescription and therefore, gives real efficacy to human right. These two approaches are seldom in nature, and cannot be upheld. Brown and Snyder, General Report, 583.

55 Onder Bakircioglu, "The Application of the Margin of Appreciation Doctrine in Freedom of Expression and Public Morality" (2007) German Law Journal 8, No.7, 713,.

56 What is decisive is the readiness of the interpreter to objectivize his/her culture-shaped mindset and to duly respect the international obligations. Thus, the need for universality is satisfied and cultural particularity is observed to the extent that the universal document explicitly or implicitly allows it. Brown and Snyder, General Report, 583. 
It is trite to mention at this juncture that, one area that has eluded efforts at international regulation is abortion. Tribunals and similar bodies involved in the implementation of international human rights laws have cautiously avoided taking a clear position on this subject, given the existence of wide disagreement from one country to another. The European Court of Human Right have therefore evoked what it calls the 'margin of appreciation' doctrine by which controversial matters (like abortion) on which there is no consensus are not addressed, thereby declining a pronouncement on the subject. ${ }^{57}$ This further reveal that international courts are careful in their pronouncements in order to give credence to the fundamental principle of international human right law.

\section{Recommendations}

Based on the study above, the following recommendations are proffered;

i) All international human right law that do not accord right to life to life to the unborn should be declared null and void.

ii) In terms of nomenclature, all human right laws should include the 'unborn child' as among human beings to be accorded the right to life.

57 Although the doctrine was first used within the frame work of the European Court system, it has been transplanted to the jurisprudence of other international human rights mechanisms. The United Nation Human Right Committee has implicitly employed the doctrine in the case of Shirin Aumeeruddy-Cziffra and 19 other Mauritanian women v. Mauritius. Bakircioglu, "Margin of Appreciation", 713 The United Nations Human Right Committee has also avoided the question of abortion. The closest the committee had come to the subject was its admonition in its general comment on the equality between men and women of March 2000, that States provide information on any measures to help women prevent unwanted pregnancies and 'ensure that they do not have to undergo life-threatening clandestine abortion'. "Human Rights Committee, General Comment 28, Equality of rights between men and women (article 3)", U.N. Doc. CCPR/C/21/ Rev.1/Add.10 (2000), Human Rights Library http://www1.umn.edu/humanrts/gencomm/ hrcom28.htm (accessed March 27, 2012). The texts themselves lend support to the view that there is some protection for the life of the unborn. They tend to rebut the arguments of those who maintained that abortion is authorized by international laws, because the unborn are not yet human beings, and therefore, they are not protected. David P. Forsythe, Encyclopedia of Human Rights Volume 1 (Oxford NY: Oxford University Press, 2009), 445-446. 
iii) All member states of the United Nations must as a matter of compliance with natural law insist that right to life be accorded to the unborn in their respective countries.

iv) The United Nations should sensitive the whole world that CEDAW was founded on natural law and hence, does not provide for abortion.

\section{Conclusion}

Upholding the fundamental principle of international human right instruments lies on the legislature of every sovereign state as the primary defenders of the human rights of the unborn children. Therefore, world politicians must conform to the universally recognized rights, as enshrined in the Universal Declaration of Human Rights as well as all other international human right laws, to which states are committed. States must provide legal protection against abortion which constitutes arbitrary deprivation of life in breach of the fundamental principles of international human rights laws. By the criminalization of abortion, the state is providing legal protection against abortion, and consequently upholding the fundamental principles of international human rights law.

It is here stated, based on the above assertions that the fundamental principle of international human right instrument is to uphold the dignity and sanctity of human persons, whether born or unborn. Therefore, no international human right instrument should be used to perpetrate an act which is against such principle.

\section{References}

Anika Rahman, Laura Katzive and Stanley k. Henshaw, "A Global Review of Laws on Induced Abortion, 1985-1997" (1998) International Family Planning Perspectives 24, no.2, 57. http://www.guttmacher.org/pubs/journals/2405698.html/ (accessed November 20, 2011).

Anjuwon G, Auston I, Raghavan R, Kotzin S and Hofman K.J., "Assessment of Scholarly Publications of the Nigerian Health Science Researchers in MEDLINE/PubMed (1996-2007)" 
(2011) Sierra Leone Journal of Biomedical Research 3, No.2, 90. http://www.ajol.info/index.php/sljbr/article/view/71809 (accessed April, 19 2012).

Campbell McLachlan, "The Principle of Systematic Integration and Article 31(3)(c) of the Vienna Convention" International and Comparative Law Quarterly 54, No.2 (2005) 279-320.

Capelon R, Zampas C, Brusie E and Devore J, "Human Rights Begins at Birth: International Law and the Claim for Fetal Rights" (2005) Reproductive Health Matters 13, No.26, 120129.

CEDAW and the Reporting Process to the Committee on the Elimination of Discrimination against Women: A Guide for UNICEF field Staff (2009) 7<http://www.crin.org/docs/ CEDAW.pdf $>$ Accessed $16^{\text {th }}$ April 2012.

Charles Malik, International Bill of Human Rights, United Nations Bulletin, 1948. http://www.udhr.org/history/ibrmalik.htm (accessed January 29, 2013).

Cheshmak Farhoumand-Sims, "CEDAW and Afghanistan" (2009) 11(\#1) Journal of International Women's Studies 136-156, http://www.bridgew.edu/soas/jiws/Nov09/Cheshmak.pdf Accessed 16th April 2012.

Christopher McCrudden, "Human Dignity and Judicial Interpretation of Human Rights" (2008) European Journal of International Law 19, No.4, 655-724.

Congressional Record V. 145 pt 18, October 141999 to October 25 1999 at 26023.

Congressional Record V. 148, pt 13, September 20, 2002 to October $12002(2006) 17954$.

David Kennedy, "The Sources of International Law" American University Journal of (1987)International Law Review 2, No.1, 1-96, http://www.auilr.org/pdf/2/2-1-1.pdf (accessed April 9, 2012). 
David P. Forsythe, Encyclopedia of Human Rights, Vol. 1, (Oxford NY: Oxford University Press, 2009.

Dennis R. Alexander and Ronald L. Numbers, Biology and Ideology from Descartes to Dawkins, (Chicago, London: University of Chicago Press, 2010).

Emily Jackson, Regulating Reproduction: Law, Technology and Autonomy, (Oxford: Hart Publishing, 2001).

Eva Brems, Human Rights: Universality and Diversity, (The Hague: Nijhoff, 2001).

George J. Annas and Michael A. Grodin, The Nazi Doctors and the Nuremberg Code: Human Right in Human Experimentation, (Oxford NY: Oxford University Press, 1995.

Hanna Beate Schopp-Schilling, "The Role of the Convention on the Elimination of all forms of Discrimination Against Women and its Monitoring Procedures for Achieving Gender Equality in Political Representation" (2004) 3. <http://www.quotaproject. org/CS/CS_Cedawbudapest04BSS.pdf $>$ Accessed $3^{\text {rd }}$ April 2012.

Hans Kelsen, General Theory of Law and State, (Clark NJ: Lawbook Exchange, 2007).

Heikki Ikheimo and Arto Laitinen, "Dimensions of Personhood" Journal of Consciousness Studies, (2007)14 No.5-6, 6-12.

Henry Drummond, Natural Law in the Spiritual World, (Rockville MD: Arc, Manor Publishers, 2008).

Hoveyda Fereydoun, "The Universal Declaration and 50 Years of Human Rights" (1998) Transnational Law and Contemporary Problems 8, 429-435.

Human Rights Committee, General Comment 28, Equality of rights between men and women (article 3)", U.N. Doc. CCPR/C/21/ Rev.1/Add.10 (2000), Human Rights Library http://www1. 
umn.edu/humanrts/gencomm/hrcom28.htm (accessed March 27, 2012).

John Austin and Robert Campbell, Lectures on Jurisprudence, or the Philosophy of Positive Law, (Clark NJ: The Law Book Exchange, 2004).

John Finnis, Natural Law and Natural Right, (Oxford, NY: Oxford University Press, 2011).

Karen B. Brown and David Snyder, General Report of the XVIIIth Congress of the International Academy of Comparative Law/ Rapports Generaux Du XIII Condress De L'Academie Internationale De Droit Compare, Dordrecht, London: Springer, 2012.

Key element no 14 under recommendation no. 24 of the CEDAW committee. <www.un.org/womenwatch/daw/ cedaw/recommendations/recomm.htm $>$ Accessed $3^{\text {rd }}$ April 2012.

L. Oppenheim, International Law $8^{\text {th }}$ Edition, (London: Longman, 1955).

Lars Adam Rehof, Guides to the Tranvaux Preperatories of the United Nation Convention on the Elimination of All forms of Discrimination against Women, (Dordrecht: Nijhoff, 1993).

Leena Grover, "A Call to Arms: Fundamental Dilemmas Confronting Interpretation of Crimes" (2010) European Journal of International Law 21, No.3, 543-583, http://www.lexisnexis. com.eserv.uum.edu.my/ap/academic/ (accessed April 19, 2012).

Ligia M. De Jesus, "Re-Visiting Baby Boy V. United States: Why the IACHR Resolution did not effectively Undermine the Inter-American System on Human Rights' Protection of the Right to Life from Conception" (2011) Florida Journal of International Law, 23, 136-226. 
Lindholm Tore, "Article 1" in The Universal Declaration of Human Right: A Common Standard of Achievement eds. Godnundur Alfredson and Asbjorn Eide, (The Hague: Nijhoff, 1999).

Luisa Blanchfield, United Nation's Convention on the Elimination of All forms of Discrimination against Women (CEDAW): Issues in the US Ratification Debate, Congressional Research Service, 2010.

Maja Kirilova Erickson, Reproductive Freedom: In the Context of International Human Rights and Humanitarian Law, (Netherlands: Kluwer La International, 2000).

Makau Mutua, "Standard Setting in Human Rights: Critique and Prognosis" (2007) Human Right Quarterly 29, 547-630.

Mary Ann Glendon, A World Made New, (New York: Random House, 2001).

Michael Weiler and W. Barnett Pearce, Regan and Public Discourse in America, (Alabama: University of Alabama Press, 1992).

Morsink Johannes, "Women's Right in the Universal Declaration" (1991) Human Right Quarterly 13, 229-256.

Nancy Ehrenreich, The Reproductive Rights Reader: Law, Medicine and the Construction of Motherhood, (New York : University Press Books, 2008).

Onder Bakircioglu, "The Application of the Margin of Appreciation Doctrine in Freedom of Expression and Public Morality" (2007) German Law Journal 8, No.7, 711-734.

Patrick J. Flood, "Does International Law Protect the Unborn Child?" in Life and Learning XVI: Proceedings of the Sixteenth University Faculty of Life Conference at Villanova.

University, 2006 ed. Joseph W. Koterski (Washington DC: University Faculty of Life, 2007), 3. 
Rebecca J. Cook, Human Rights of Women: National and International Perspective, (Philadelphia: University of Pennsylvania Press, 1994).

Report of the Committee on the Elimination of all forms of Discrimination against Women' Twentieth Session $\left(19^{\text {th }}\right.$ January- $5^{\text {th }}$ February 1999), Twenty-First Session $\left(7^{\text {th }}-25^{\text {th }}\right.$ June 1999), General Assembly Official Records, fifty-fourth Session Supplement No. 38 (A/54/38/Rev.1). <www.un.org/ womenwatch/daw/cedaw/reports/21 report.pdf $>$ Accessed $3^{\text {rd }}$ April 2012.

Rita Joseph, Human Right and the Unborn Child, (Leiden, Boston: Martinus Nijhoff Publishers, 2009).

Roy Ridgway and Simon H. House, The Unborn Child: Beginning of a Whole Life and Overcoming Problems of Early Origin, (London: Karnac, 2006).

Samuel M. Natale and Mark B. Fenton, Business Education and Training: On the Threshold of the Millennium (Lanham Md: University Press of America, 2000).

Shirin Aumeeruddy-Cziffra and 19 other Mauritanian women $v$. Mauritius Communication No. R.9/35, U.N. Doc. Supp. No. $40(\mathrm{~A} / 36 / 40)$ at $134(1981)$.

Siegrid Tautz, "(un) safe Abortion, A Review and Discussion Paper" Federal Ministry for Economic Cooperation and Development. Health and Population, Supraregional Project: Promotion of Reproductive Health. 4320 (2004): 1-33. http:// www.giz.de/Themen/de/dokumente/de-disk-ssa4(1).pdf (accessed November 20, 2011).

Stephen P. Marks, "From Single Confused Page to the Dialogue for Six Billion Persons: The Root of the Universal Declaration of Human Rights in the French Revolution" Human Right Quarterly (1998) 20, No.3, 459-514.

Susan Cohen, "Facts and Consequences: Legality, Incidence and Safety of Abortion Worldwide" Guttmacher Policy Review 
12, no.4 (2009). http://www.guttmacher.org/pubs/gpr/12/4/ gpr120402.html (accessed June 15, 2012).

Suzzane Mclntire and William E. Burns, Speeches in World History, (New York: Facts on File, 2009).

Thomas Acquina, Question 90-7 of the first part of the second part of his Summa Theologiae. http://www.fordham.edu/halsall/ source/aquinas1.asp (accessed June 2, 2013)

Universal Declaration of Human Right. G.A Res. 217(A) (III), UN GAOR, $3^{\text {rd }}$ Sess, Supp. No 127 at 71, UN Doc A/180 (1948).

Van Aggelen Johannes, "The Preamble of the United Nations Declaration of Human Rights" (2000) Denvor Journal of International Law and Policy 28, No.2, 129-144.

Vicki C. Jackson, "Constitutional Dialogue and Human Dignity: States and Transformational Constitutional Discourse" Montana Law Review 65, 15-40.

Vienna Convention of the Law of Treaties 1969.

William A. Scabas, The Abolition of the Death Penalty in International Law, $2^{\text {nd }}$ ed., (Cambridge UK: Cambridge University Press, 1997).

William E. May, Introduction to Moral Theology, (Huntington: Our Sunday Visitor Publication,2003). 